\title{
ASSESSING THE RELATIONSHIP BETWEEN MATERIALISM AND CONSPICUOUS CONSUMPTION: VALIDATION IN THE INDIAN CONTEXT
}

\author{
Pearly Saira Chacko ${ }^{1 *}$, Sanjeev Prashar ${ }^{2}$, and Hareesh N. Ramanathan ${ }^{1}$ \\ ${ }^{1}$ Toc H Institute of Science and Technology, Arakkunnam, \\ P.O. Ernakulam District, Kerala, India \\ ${ }^{2}$ Indian Institute of Management (IIM) Raipur, Old Dhamtari Road, Sejbahar, \\ Raipur-492015, Chhattisgarh, India \\ *Corresponding author: zairapearls@gmail.com
}

Published online: 21 December 2018

To cite this article: Chacko, P.S., Prashar, S., and Ramanathan, H.N. (2018). Assessing the relationship between materialism and conspicuous consumption: Validation in the Indian context. Asian Academy of Management Journal, 23(2), 143-159. https://doi.org/10.21315/ aamj2018.23.2.7

To link to this article: https://doi.org/10.21315/aamj2018.23.2.7

\begin{abstract}
With urbanisation and increase in per capita income, there has been an astonishing rise in material-oriented tendencies in the Indian population. This study aims to examine the significance of material-centric behaviour of women in today's growing consumer societies. Using structural equation modelling, the paper proposes a model depicting the relationship between materialism and conspicuous consumption among Indian women consumers. Though all the three factors, namely success, centrality, and happiness, contribute to materialism that has a positive influence on conspicuous consumption, the unique finding of the study is the prominence of centrality over the other two predictors among Indian female shoppers.
\end{abstract}

Keywords: materialism, conspicuous consumption, happiness, centrality, success

\section{INTRODUCTION}

India's rapid economic growth, post the liberalisation reforms of 1991, has set the stage for fundamental change among the consumers. Increased alternatives in consumer funding and lowering of interest rates by financial institutions over the

(C) Asian Academy of Management and Penerbit Universiti Sains Malaysia, 2018. This work is licensed under the terms of the Creative Commons Attribution (CC BY) (http://creativecommons. org/licenses/by/4.0/). 
past decade, along with the ability of the nation to curb price rises at reasonable levels have resulted in an increase of earnings of the middle and the affluent classes in India (Kumar \& Sarkar, 2008). With the increase in per capita income, there has been an extraordinary rise in material orientation among the Indian population. This study aims at deciphering the impact of materialism on conspicuous consumption in one of the least researched but rapidly emerging economies in the world.

Materialism refers to the excessive importance given by people to material objects in one's life (Goldsmith \& Clark, 2012). Conspicuous consumption, on the other hand, indicates the wasteful buying practices and leisure activities that aim to label association with a superior social class (Georgios \& Fitchett, 2012). Though materialism and conspicuous consumption have traditionally been the Western doctrines, these practices are now gaining prevalence in Asian countries. "Global Attitudes on Materialism, Finances and Family" reported China (71\%) and India (58\%) topping the rankings as the most materialistic countries based on the importance consumers give to their own and others' success by the superiority of possessions they own (IPSOS, 2013). These changes could be attributed to the transformation in the traditional moral system and changes in the social structure. Podoshen, Li, and Zhang (2010) observed that this has disturbed those who position for strongly held values and long-established ways of life. Rapid deteriorating of such values to amass material assets is their major concern.

Globalisation and increase in disposable incomes have brought in attitudinal changes among the emerging Indian middle-class population. Though the IPSOS survey results have confirmed the observation regarding the escalating middleclasses in India, however, the study was limited as attitude towards materialism was measured using a single item construct ("I measure the success by the things that I owned"). The methodology adopted had chances of vague understanding that could have tampered with the quality of responses. To build the robustness in the research design aimed at assessing the relationship between materialism and conspicuous, it was decided to measure the materialistic attitudes using a series of validated statements that will result in more accuracy.

Existing studies on materialism and conspicuous consumption in Indian context like Jaikumar and Sarin (2015), Khamis, Prakash, and Siddique (2012), and Kumar and Sarkar (2008) have independently explored the two variables and their antecedents. However, these studies did not explore the significance of materialistic tendencies on the conspicuousness of an individual. With societal transformation in family structures, education, and increased income, the role of women in the family has changed. Women in India have evolved both professionally and as new decision makers owing to their financial independence (ASSOCHAM, 2016). Studies also 
indicate the increasing influence of materialism in India (Chaudhuri \& Haldar, 2005; Gupta, 2011; Manchanda, Abidi, \& Mishra, 2015; Chacko \& Ramanathan, 2015). In this context, the present study attempts to measure the relationship between materialism and conspicuousness among women with regard to their newly found financial independence. The research claims to develop a model explaining the relationship between materialism and conspicuous consumption using structural equation modelling (SEM).

Fulfilling the study gap, the present paper has been structured as follows. An extensive review of the literature on the related constructs has been presented in the next section. This is followed by research methodology and analysis of data obtained from the survey. Later, the finding and discussions have been presented.

\section{LITERATURE REVIEW}

Materialism and conspicuous consumption is one of the most important facets of consumer behaviour that has gained extensive significance in the last decade. It is an aspect which has been widely researched and written because of the importance it had in the growth of consumerism (Scott, Martin, \& Schouten, 2014).

\section{Conspicuous Consumption}

The term conspicuousness in the dictionary means clearly visible, obvious, and showy. Though Veblen is credited as the originator of the term conspicuous consumption, he was not the first; there were many who discussed it even before. The history of conspicuous consumption can be traced as far-flung as the early civilisation where the rulers and the aristocrats adorned themselves with rare stones, fabrics, and jewellery and lavished with ceremonies to showcase their wealth (Ray, 2009). However, the notion of conspicuousness has evolved over the years. With globalisation and privatisation, as the economic scenario started to transform, people became exposed and aware of the better choices of life partook in flamboyant spending which till that point was only reserved for the upper class (Memushi, 2013). Ostentation behaviour which were also seen among nobility during the pre-capitalist feudal era, was exhibited by upper middle class too during the modern capitalist era either for signalling uniqueness or to display social standing. However, in the postmodern age, conspicuousness is no longer a privilege of the upper class but a widespread behaviour among the middle class "masses" who are driven by self-expression (Chaudhuri \& Majumdar, 2006; Memushi, 2013). Today ostentatious consumption behaviour has become more suave and elusive (Trigg, 2001). 
Various studies in conspicuous consumption have attributed the motive of ostentatious spending as to project one's image in the society. Schiffman and Kanuk (2004) defined social status as the stratification into different hierarchical social classes based on the factors like wealth, power, and prestige. In societies where status is prominent, brands are consumed to express a strong message about the consumer (O'Cass \& Frost, 2002) and also owning a certain brand may also be figurative of a particular group membership (Wong \& Zhou, 2005). The prestige seeking behaviour of people is because of two major reasons; one being selfexpression and the other social status (Vigneron \& Johnson, 1999).

There have been researches suggested that conspicuous consumption also have relationship objectives. A study proposed that women conspicuously consumed to deter other female contenders who cause the threat to her relationship (Wang \& Griskevicius, 2013). However, studies found that consumers find luxury products as a means of expressing their social status, display their positive self-image, and in some cultures to boost their low self-esteem (Souiden, M'Saad, \& Pons, 2011).

There are few studies on conspicuous consumption that have been undertaken in the Indian context. Profiling the expense pattern of different social groups in India on things that indicate status in the society, Khamis et al. (2012) noted more spending on visible purchases by the backward castes than by the upper caste. Also, the expenses on such purchases are more for groups that are comparatively poor in society, as they are prejudiced by the custom of signalling. Their investment in health or education was nearly negligible. Owing to the absence of alternative means to signal status, individuals from low-income groups in India tend to conspicuously spend (Jaikumar \& Sarin, 2015). The study found that Indian consumers generally perceive possession of luxury goods to echo a prosperous lifestyle (Srinivasan, Srivastava, \& Bhanot, 2014).

\section{Materialism}

The concept of materialism has been widely studied by researchers in different contexts. There have been studies that have viewed materialism in the individual as well as sociocultural perspectives, and these perspectives have evolved over time. There exists a school that pivots around the positive influence of materialism. Twitchell (1999) positioned materialism to be a foundation of pleasure and success. On the other hand, Podoshen and Andrzejewski (2012) considered materialism as a detrimental value system as it stresses on wealth and possessions at the centre of life. Here, the underlying belief is that materialism leads to happiness. As per this, materialism is an outlook on life categorised by the quest for riches and belongings. 
Using a positivistic outlook, Bell (1984) considered materialism to be a component of a person's personality trait whereas according to Richins and Dawson (1992), materialism is considered as a value. Accordingly, materialism represents a set of centrally held beliefs about the significance of possessions in one's life. To measure an individual's materialistic values, a scale with three dimensions - centrality, happiness, and success - was developed. This material value scale (MVS) has been adopted by the researchers to undertake the present study. Studies like Müller et al. (2013) and Lipovčan, Prizmić-Larsen, and Brkljačić (2015) have validated MVS of Richins and Dawson (1992) in select cultural contexts (Jankovic \& Dittmar, 2006).

Another study found that the outcome of materialism could be positive or negative depending upon its three facets: success, centrality, and happiness (Segev, Shoham, \& Gavish, 2015). The study found that acquisition of material possessions helps consumers cope up or overcome negative feelings. Meaning to say that material good helps in negating any state of damaging emotions. Centrality and happiness were also found to be positively related to attachment (Dingus, 2014).

Another study conducted to understand the impact of materialism on subjective wellbeing in three countries - UK, Germany, and Croatia - found that happiness was the major dimension which explained the major part of the variation in materialism in all the three countries (Jankovic \& Dittmar, 2006). However, the acquisition of material goods was not considered a symbol of success and achievement in any of the three countries. However, Twitchell (1999) posits that spending and buying products enhance happiness among people. Bushra and Bilal (2014) posits that all the three traits of materialism - centrality, success, and happiness - were true predictors of materialism.

Studies conducted among north-eastern states in US reveals that materialism varies among gender (Segal \& Podoshen, 2013). Studies conducted in China reveal that the materialistic tendencies of both men and women are on a high. However, women consider the acquisition of possession to be more important (Workman \& Lee, 2011). Studies in China, one of the fastest growing economy in the world, found that young Chinese consumers are being turned into consumerism as they believe that possessions of products will lead to greater levels of happiness and satisfaction (Fang \& Podoshen, 2017).

One of the studies on materialism in India (Chaudhuri \& Haldar, 2005) investigated the influence of culture and geographical subcultures on materialism. They found the strong significant correlation between regional cultural adherence and desire 
for purchasing materialistic goods. Another study was conducted to analyse the inclination of materialistic values among Indian consumers and the study posits that materialistic values were highest for lower-middle-class income segment visà-vis the middle class and upper-middle-class segments (Gupta, 2011).

\section{HYPOTHESIS DEVELOPMENT AND MODEL}

According to Richins and Dawson (1992), materialism is considered as a value. Accordingly, materialism represents a set of centrally held beliefs about the significance of possessions in one's life. They proposed that materialism to have three dimensions: centrality, success, and happiness. Centrality manifests the tendency of the materialists to consider possession of worldly goods to be central to their lives. The core purpose that steers their behaviour is the act of acquisition(s). Happiness is the belief that pleasure and well-being in life can be attained through acquisition of assets. For people with high materialism, both acquisition and ownership of goods are vital in achieving fulfilment and well-being in life. Finally, success is defined as the tendency of the materialists to judge their own and other individual's accomplishment by the number and quality of wealth amassed. They use possessions to flaunt their status in the society.

In their research, Lynn and Harris (1997) have posited the relationship between materialism and conspicuous consumption. Shoppers derive contentment from others' reactions more than the functional use of the item. Material-oriented people focus on the spending on prestige, exclusive goods to differentiate themselves. There are studies from Western economies that validate this positive relationship materialism has with conspicuous consumption (Eastman, Goldsmith, \& Flynn, 1999). Though there has been a considerable growth in the expenditure on status goods among Indian consumers post-liberalisation, researchers could not come across any study of this nature in the Indian context. Hence, this study was undertaken to fill this space. Therefore, the hypothesis can be framed as follows (see Figure 1):

H1: Success is positively related to conspicuous consumption.

$\mathrm{H} 2$ : Centrality is positively related to conspicuous consumption.

H3: Happiness is positively related to conspicuous consumption. 


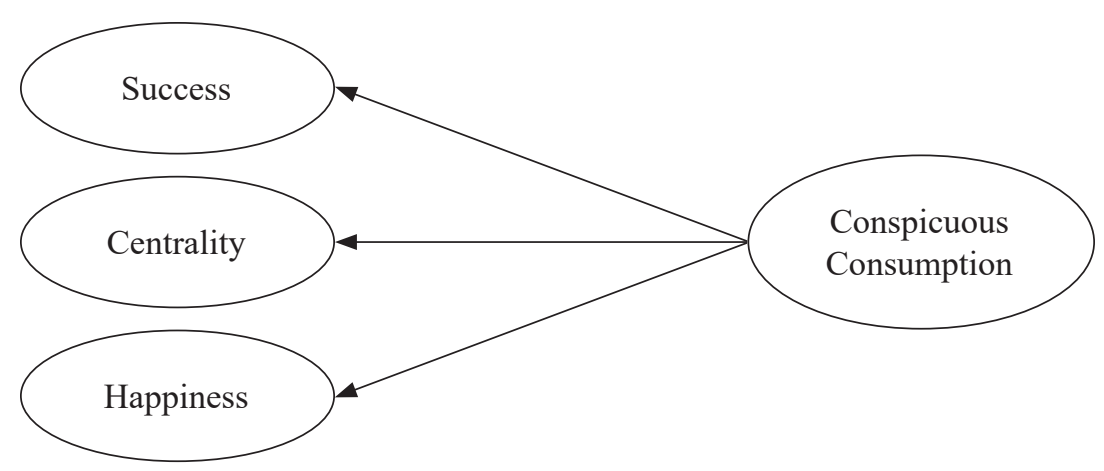

Figure 1. Conceptual framework

\section{RESEARCH METHODOLOGY}

\section{Questionnaire Development}

After a comprehensive review of the literature on conspicuous buying, materialism, and measure construct like success, centrality, and happiness, the questionnaire was constructed. This survey instrument had two parts. First part comprised of questions related to consumers' demographic characteristics. Second part pivoted around measuring the variables using a five-point Likert scale where 5 and 1 reflected "strongly agree" and "strongly disagree", respectively.

To measure the study variables, it was decided to use validated scales from existing studies. Developed by Richins and Dawson (1992), 18-items scale was used to measure materialism. Of these, the first six items measured "success" and next seven on "centrality". The remaining five items were related to "happiness". The four-item scale for "conspicuous consumption" was adapted from Chung and Fischer (2001).

In an Indian society, accumulation and possessions of the material goods have traditionally been considered as a negative value system. Finding respondents who are ready to share such information is relatively difficult. Hence, it was decided to use snowball sampling, a non-probability sampling method to the collected data. The data was collected from women through survey during first-half of 2016. The questionnaire was shared with 550 working women across four cities in India. After rejecting incomplete or wrongly filled questionnaires, data from 324 respondents were taken for final analysis. 


\section{Demographic Profile of Respondents}

Eighty-four percent of the respondents were employed with the private sector, whereas just 10 respondents were working in government agencies. The age of respondents ranged between 20 and 66 years and the average was 28 years. Most of the respondents (34.8\%) had monthly household income between INR70,000 and INR100,000, followed by $29.9 \%$ between INR50,000 and INR70,000, and $22.9 \%$ between INR100,000 and INR200,000. Three-fourth of the sample was married and $63 \%$ of the respondents were residing in semi urban and urban areas of Kerala in India.

\section{RESULTS}

With AMOS 22.0 software, SEM was used to analyse the data. A two-step approach for data analysis as suggested by Hair, Black, Babin, and Anderson (2006) was followed. Confirmatory factor analysis was conducted to estimate the measurement model, followed by testing the path analysis and the research hypothesis. To explore the relationship between materialism and conspicuous consumption, second-order confirmatory factor analysis was attempted. This statistical method is employed to confirm that the theorised construct loads into a certain number of underlying sub-constructs or components.

Various measures of statistics were used to assess the fit of data with the proposed model through confirmatory factor analysis. The ratio of chi-square minimum to the degree of freedom (CMIN/DF) was 1.364, which is below the cut-off criterion of 3.00 (Hair et al., 2006). This indicates a good fit between the data and the model. Other indices like goodness-of-fit index (GFI), comparative fit index (CFI), incremental fit index (IFI), and Tucker-Lewis index (TLI) should be greater than 0.9 , and the root mean square error of approximation (RMSEA) should be less than 0.1 (Brown, 2006; Hair et al., 2006). The values of these indices reflect that the model fits the data $(\mathrm{CMIN} / \mathrm{DF}=1.364, \mathrm{GFI}=0.971, \mathrm{CFI}=0.982, \mathrm{RMSEA}$ $=0.034$ ) (see Table 1). Thus, the hypothesised model depicting the relationship between materialism and conspicuous consumption was found to be fit for further analysis.

To measure the fit statistics, another index - expected cross-validation index (ECVI) - has also been used. This index measures the discrepancy between the covariance measure that is fitted and the expected covariance matrix that would be obtained from another sample of equivalent size. The model with smallest ECVI indicates good measure and has the greatest potential for replication. In the study, 
obtained ECVI value is 0.328 , which indicates that there can be a small discrepancy between the covariance measure that is fitted and the expected covariance matrix that would be obtained in another sample of equivalent size.

Table 1

Fit statistics of the proposed model

\begin{tabular}{lc}
\hline Indices & Observed value \\
\hline CMIN/DF & 1.364 \\
RMSEA & 0.034 \\
CFI & 0.982 \\
TLI & 0.976 \\
GFI & 0.971 \\
IFI & 0.982 \\
ECVI & 0.328 \\
\hline
\end{tabular}

Statistical significance of parameter estimates was established using t-test statistic (critical ratio). Factor loadings for the three constructs - success, centrality and happiness - were found to be greater than 0.60 and hence significant. As shown in Table 2, these high values in each case indicate convergent validity. This reflects that the three constructs contribute to materialism. Hence, the theory of three subconstructs for materialism is well supported.

Table 2

Regression path coefficients between materialism and its sub-constructs

\begin{tabular}{lcccccccc}
\hline Sub-constructs & Path & Constructs & $\begin{array}{c}\text { Factor } \\
\text { loading }\end{array}$ & Estimate & SE & CR & $p$ & Result \\
\hline Success & $\longleftarrow$ & Materialism & 0.77 & 1.414 & 0.207 & 6.818 & 0.001 & Significant \\
Centrality & $\longleftarrow$ & Materialism & 0.90 & 1.721 & 0.245 & 7.039 & 0.001 & Significant \\
Happiness & $\longleftarrow$ & Materialism & 0.71 & 1.000 & & & & Significant \\
\hline
\end{tabular}

Critical ratio values that exceed 2 are regarded as significant at the level of 0.05 ; all the regression values (estimates) were found to be significant (see Table 2).

After deleting all the items that had item loading below 0.5 , the final table is drawn (see Table 3). Only three items of the construct success were found to have factor loadings above 0.5 . For centrality, three statements out of seven were found to have factor loadings above 0.5 . Among the five statements that contribute to the sub-construct happiness, three statements were found to have loadings above 0.5 (see Figure 2). 
Table 3

Regression path coefficients between the sub-constructs and their statements

\begin{tabular}{lllllllll}
\hline $\begin{array}{l}\text { Sub- } \\
\text { constructs }\end{array}$ & Path Constructs & $\begin{array}{c}\text { Standardised } \\
\text { regression } \\
\text { weights }\end{array}$ & CR & $p$ & $\begin{array}{c}\text { Average } \\
\text { variance } \\
\text { extracted }\end{array}$ & $\begin{array}{c}\text { Construct } \\
\text { reliability }\end{array}$ & Result \\
\hline S_M4 & $\longleftarrow$ Success & 0.82 & 7.068 & 0.001 & 0.530 & 0.770 & Significant \\
S_M1 & Success & 0.62 & 7.136 & 0.001 & & & Significant \\
S_M5 & $\longleftarrow$ Success & 0.73 & & & & & \\
C_M6 & $\longleftarrow$ & Centrality & 0.73 & & & 0.504 & 0.753 & \\
C_M5 & Centrality & 0.71 & 9.459 & 0.001 & & & Significant \\
C_M4 & $\longleftarrow$ & Centrality & 0.69 & 7.962 & 0.001 & & & Significant \\
H_M5 & $\longleftarrow$ & Happiness & 0.65 & & & 0.506 & 0.750 & \\
H_M4 & $\longleftarrow$ & Happiness & 0.85 & 9.535 & 0.001 & & & Significant \\
H_M2 & $\longleftarrow$ Happiness & 0.61 & 8.420 & 0.001 & & & Significant \\
\hline
\end{tabular}

Note: S_M4: The things I own say a lot about how well I'm doing in life

S_M1: I admire people who own expensive homes, cars, and clothes

S_M5: I like to own things that impress people

C_M6: I like a lot of luxury in my life

C_M5: Buying things gives me a lot of pleasure

C_M4: I enjoy spending money on things that aren't practical

H_M5: It sometimes bothers me quite a bit that I can't afford to buy all the things I'd like

H_M4: I would be happier if I could afford to buy more things

H_M2: My life would be better if I owned certain things I don't have

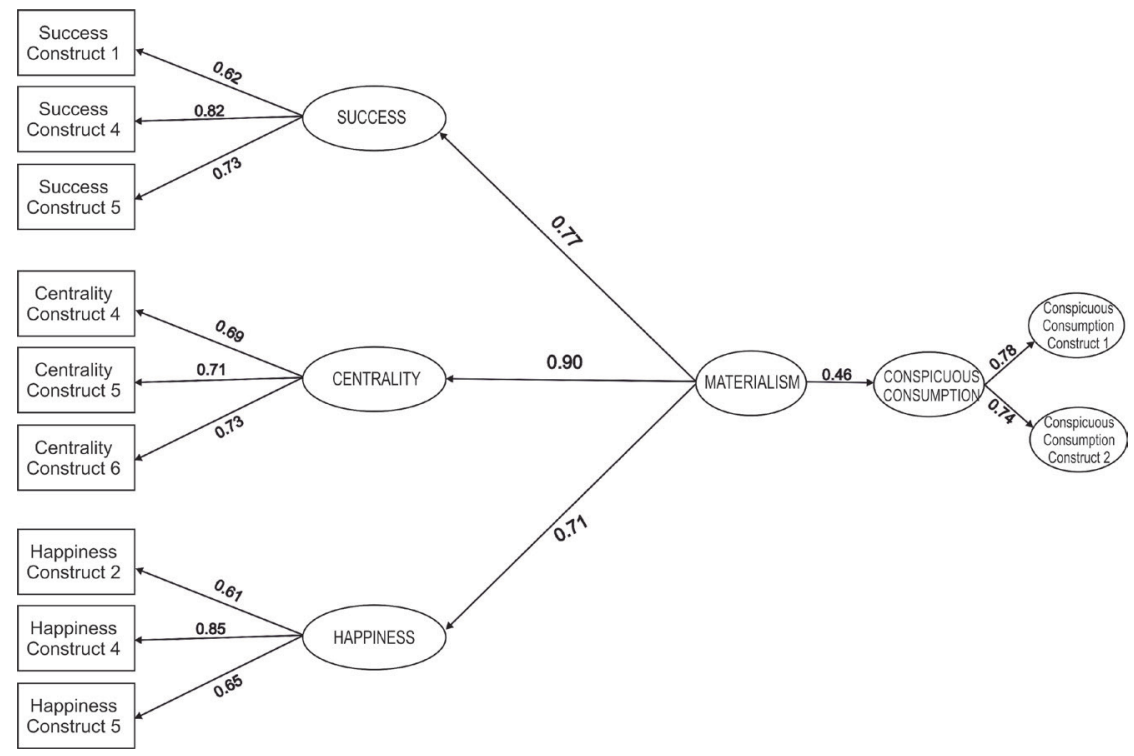

Figure 2. Model fit summary 
Only two statements out of the four that constituted conspicuous consumption were found to have loadings above 0.5 , and hence they were significant (see Table 4). It is supported as the CR values were found to be greater than 2 and hence significant at $p<0.00$.

Table 4

Regression path coefficients between conspicuous consumption and its sub-constructs

\begin{tabular}{lccccccc}
\hline $\begin{array}{l}\text { Sub- } \\
\text { constructs }\end{array}$ & Path & Constructs & $\begin{array}{c}\text { Standardised } \\
\text { regression } \\
\text { weights }\end{array}$ & $\begin{array}{c}\text { Average } \\
\text { variance } \\
\text { extracted }\end{array}$ & CR & $p$ & Result \\
\hline $\mathrm{CC} 1$ & $\longleftarrow \begin{array}{c}\text { Conspicuous } \\
\text { consumption }\end{array}$ & 0.78 & 0.578 & & & Significant \\
$\mathrm{CC} 2$ & $\longleftarrow \begin{array}{l}\text { Conspicuous } \\
\text { consumption }\end{array}$ & 0.74 & & 6.336 & 0.001 & Significant \\
\hline
\end{tabular}

\section{Hypothesis Testing}

The association between the two key variables was examined. Testing the hypothesis that materialism leads to conspicuous consumption was found to be significant $(p<0.05)$ with R2 as 0.46 (Table 5). Thus, H1 is accepted. This indicates that $46 \%$ of the variation in conspicuous consumption could be attributed to materialism.

Table 5

Regression path coefficients between materialism and conspicuous consumption

\begin{tabular}{lccccc}
\hline Construct & Path & Construct & $\begin{array}{c}\text { Standardised } \\
\text { regression weights }\end{array}$ & $p$ & Result \\
\hline Conspicuous consumption & $\longleftarrow$ & Materialism & 0.46 & 0.05 & Significant \\
\hline
\end{tabular}

\section{DISCUSSION}

While many researchers have documented materialism as an antecedent of consumer behaviour (Mai \& Tambyah, 2011; Podoshen, Li, \& Zhang, 2010), there have been only a few studies on the topic in a transition economy like India, and that too in the context of women consumers. In the present paper, researchers have attempted to study these variables in the context of a diverse cross-section of Indian women consumers. The primary objective was to examine the influence of the three dimensions of materialism on conspicuous consumption, if any, besides validating MVS in the Indian context. The confirmatory factor analysis proved 
the presence of all the three subfactors namely success, centrality, and happiness, which is consistent with the findings of Richins and Dawson (1992).

The present study validates the relationship between these materialistic factors and conspicuous consumption in the context of emerging world economies like India. The results validate a significant positive association between the two constructs implying that materialism has a positive influence on conspicuous consumption. This finding is also in congruence with prior researches done in Western societies (Wong, 1997; Podoshen et al., 2010; Goldsmith \& Clark, 2012).

The prominent finding from the statistical analysis indicates that both the internal elements of materialism (stimuli) - happiness and centrality - and the external element, success - contribute to conspicuous consumption. Though all the three predictor variables were found to affect conspicuous consumption, their relative influence varied. Analysing the empirical results further, it is revealed that centrality is the strongest predictor of conspicuous consumption among Indians, while happiness has a relatively least influence on such consumption among Indian women. It could be inferred that female shoppers' value centrality, which essentially means giving significance to amassing materialistic elements as opposed to gratifying their inner morals. This finding is in line with another study conducted in another emerging Asian economy, Pakistan. Assessing the dimensions of materialism, status consumption and post-purchase guilt, Bushra and Bilal (2014) observed that acquisition centrality has an exceedingly significant positive impact on materialism. Using Richins and Dawson scale to measure materialism in the US, Dingus (2014) also noted a much higher score for centrality as compared to the other two components, i.e., success and happiness. However, it was contrasted by a study by Lipovčan et al. (2015) that observed the prominence of happiness over centrality and success among respondents in Croatia. This could be because of the cultural as well as the economic difference between the two markets. Success is the second prominent predicting variable among Indian women shoppers.

Extending the conclusions of the previous studies, this research data support Richins (1994) observation that materialism leads to the need for acquiring goods that denote status. Explaining success through possession, Richins and Dawson (1992) defined it to be the tendency of materialists to judge the success of people by the number and quality of possessions accumulated. Similarly, acquisition centrality is the tendency to place such possessions and the process of getting possessions as the pivot of their lives. Given the data in this study, it can be inferred that female consumers in India tend to concern themselves greatly with the public meaning of possessions. Success and centrality are key influencers of materialism today. In a German study, it was noted that women are equally oriented towards 
centrality and success (Müller et al., 2013). In a cross-country validation research on materialism, Jankovic and Dittmar (2006) observed that centrality dimension was higher among UK consumers.

This paper also confirms the findings of the study like Chaudhuri and Majumdar (2010) that suggested the influence of happiness and centrality on conspicuous consumption. Also, as noted in studies like Podoshen and Andrzejewski (2012) and Richins and Dawson (1992), the present study concludes that success, happiness, and centrality are the sub-traits of "materialism", and people valued centrality more than the happiness dimension.

\section{MANAGERIAL IMPLICATIONS}

The outcomes of the present study offer much-desired cues for marketers in developing their action plans. The rise of materialism provides opportunities for marketers to devise their advertising campaigns in such a way to bring about the importance of buying a product or service. Though all the three factors - success, centrality, and happiness - contribute to materialism, which in turn has a positive influence on conspicuous consumption, centrality component of materialism has much higher prominence in predicting the conspicuousness of the Indian female shoppers. For the products that have a very high-status appeal, marketers must use "enhanced personality" or "improved status" as their promotional campaigns. The process of acquiring such products may be projected as a celebration of an "event" in consumers' life. Belk, Ger, and Askegaard (2003) has suggested the role that consumer imaginations and desires can play in exciting the potential markets for creating longings for such products. Campaigns/sales talks promising "magical moments in life" can easily convert potential buyers into consumers. Marketers can activate the latent needs and desires of the shoppers using the cues pivoted around the elements of materialism (O'Shaughnessy \& O'Shaughnessy, 2002).

\section{CONCLUSION}

The results of the present study throw light on important aspects related to materialism and conspicuous consumption that earlier researchers have not fully explored in our cultural framework. The study validated the three-factor MVS construct of materialism in Indian scenario using confirmatory factor analysis. It also contributes to the present body of knowledge on buying behaviour in the context of conspicuous consumption, specifically for those who have academic and strategic marketing interest in developing economies like India. Centrality 
and success dimensions were found to be vital with respect to conspicuous consumption. In other words, females with higher concern for displaying their success and social image are more likely to conspicuously consume. This provides an opportunity for enterprises and marketers to allure their clients using strategies that invoke exclusivity and triumph.

\section{LIMITATIONS AND DIRECTION FOR FUTURE RESEARCH}

Like other studies based on data collection, this study too has few limitations. Data has been collected from Indian women respondents. Though the study used data from India, the perception of people may vary from region to region hence limiting the general conclusion of the study. Future research should examine these differences among Indian consumers in other cities too. Another limitation is that the research considers only the relationship between materialism and conspicuous consumption. Since research on luxury purchase behaviour is in the nascent stage, research could be extended to include other factors related to consumer behaviours like personality, demographics, and impulsive tendency. The effect of age, religion, spirituality, and education on materialism and conspicuous consumption has not been studied in this research. Future research can also be done on the relative impact of functional, personal, and social value perceptions because value perceptions have a major impact on luxury purchase intention (Chattalas \& Shukla, 2015). On the contrary, the perception of luxury has now transformed from premium luxury to consumers experience "luxury" or "affordable luxury" in emerging markets. Such a hypothesis should also be tested using empirical studies.

\section{REFERENCES}

ASSOCHAM (The Associated Chambers of Commerce \& Industry of India). (2016). Indian luxury market to cross $\$ 18.3$ bln by 2016 ; India's luxury market likely to break all times record in 2016: ASSOCHAM paper. Retrieved 14 February 2017 from http://www.assocham.org/newsdetail.php?id $=5440$

Belk, R.W., Ger, G., \& Askegaard, S. (2003). The fire of desire: A multi-sited inquiry into consumer passion. Journal of Consumer Research, 30(3), 326-351. https://doi. org $/ 10.1086 / 378613$

Bell, R.W. (1984). Three scales to measure constructs related to materialism: Reliability, validity, and relationships to measures of happiness. Advances in Consumer Research, 11, 291-297.

Brown, T. (2006). Confirmatory factor analysis for applied research. New York: The Guilford Press. 
Bushra, A., \& Bilal, A. (2014). The relationship of compulsive buying with consumer culture and post-purchase regret. Pakistan Journal of Commerce and Social Sciences, 8(3), 590-611.

Chacko, P.S., \& Ramanathan, H.N. (2015). Materialism and conspicuous consumption: The extend matters. A study among the consumers in Kerala. International Journal of Emerging Research in Management \& Technology, 4(5), 381-387.

Chattalas, M., \& Shukla, P. (2015). Impact of value perceptions on luxury purchase intentions: A developed market comparison. Luxury Research Journal, 1(1), 4057. https://doi.org/10.1504/LRJ.2015.069806

Chaudhuri, H.R., \& Majumdar, S. (2006). Of diamonds and desires: Understanding conspicuous consumption from a contemporary marketing perspective. Academy of Marketing Science Review, 11, 1-18.

Chaudhuri, H.R., \& Majumdar, S. (2010). Conspicuous consumption: Is that all bad? Investing the alternative paradigm. Vikalpa: The Journal for Decision Makers, 35(4), 53-59.

Chaudhuri, H.R., \& Haldar, A.K. (2005). Understanding the interrelationship between regional differences and material aspiration in the context of Indian diversity: Results of an exploratory study. Asia Pacific Journal of Marketing and Logistics, 17(4), 3-14. https://doi.org/10.1108/13555850510672403

Chung, E., \& Fischer, E. (2001). When conspicuous consumption becomes inconspicuous: The case of the migrant Hong Kong consumers. Journal of Consumer Marketing, 18(6), 474-487. https://doi.org/10.1108/07363760110404378

Dingus, R. (2014). Like it, love it, or gotta have it: Relating materialism and attachment. Atlantic Marketing Journal, 3(3), 38-47.

Eastman, J., Goldsmith, R.E., \& Flynn, L. (1999). Status consumption in consumer behavior: Scale development and validation. Journal of Marketing Theory and Practice, 7(3), 41-52. https://doi.org/10.1080/10696679.1999.11501839

Fang, Y., \& Podoshen, J. (2017). New insights into materialism and conspicuous consumption in China. Journal of Consumer Ethics, 1(2), 72-81.

Georgios, P., \& Fitchett, J.A. (2012). The evolution of conspicuous consumption. Journal of Historical Research in Marketing, 4(1), 154-176. https://doi.org/ 10.1108/17557501211195109

Goldsmith, R.E., \& Clark, R.A. (2012). Materialism, status consumption, and consumer independence. The Journal of Social Psychology, 152(1), 43-60. https://doi.org/1 $0.1080 / 00224545.2011 .555434$

Gupta, N. (2011). Globalization does lead to change in consumer behaviour: An empirical evidence of impact of globalization on changing materialistic values in Indian consumers and its aftereffects. Asia Pacific Journal of Marketing and Logistics, 23(3), 251-269. https://doi.org/10.1108/13555851111143204

Hair, J.F., Black, W.C., Babin, B.J., \& Anderson, R.E. (2006). Multivariate data analysis. New Jersey: Pearson Prentice Hal.

IPSOS. (2013). The global trends survey: A public opinion report key challenges facing the world. London: IPSOS. 
Jaikumar, S., \& Sarin, A. (2015). Conspicuous consumption and income inequality in an emerging economy: Evidence from India. Marketing Letters: A Journal of Research in Marketing, 26(3), 11002-11015.

Jankovic, J.F., \& Dittmar, H. (2006). The componential nature of materialistic values and subjective well-being: A comparison of students in Croatia, Germany, and the UK. In A. Delle Fave (Ed.), Dimensions of well-being: Research and intervention (pp. 34-52). Milano: FrancoAngeli.

Khamis, M., Prakash, N., \& Siddique, Z. (2012). Consumption and social identity: Evidence from India. Journal of Economic Behavior \& Organization, 83(3), 353-371. https://doi.org/10.1016/j.jebo.2012.07.002

Kumar, R.V., \& Sarkar, A. (2008). Psychographic segmentation of Indian urban consumers. Journal of the Asia Pacific Economy, 13(2), 204-226. https://doi. org/10.1080/13547860801923590

Lipovčan, L.K., Prizmić-Larsen, Z., \& Brkljačić, T. (2015). Materialism, affective states, and life satisfaction: Case of Croatia. SpringerPlus, 4, 699. https://doi. org/10.1186/s40064-015-1494-5

Lynn, M., \& Harris, J. (1997). The desire for unique consumer products: A new individual differences scale. Psychological Marketing, 14, 601-616. https://doi.org/10.1002/ (SICI)1520-6793(199709)14:6<601::AID-MAR5>3.0.CO;2-B

Mai, N.T., \& Tambyah, S.K. (2011). Antecedents and consequences of status consumption among urban Vietnamese consumers. Organizations and Markets in Emerging Economies, 2(3), 75-98.

Manchanda, R., Abidi, N., \& Mishra, J.K. (2015). Assessing materialism in Indian urban youth. Management, 20, 181-203.

Memushi, A. (2013). Conspicuous consumption of luxury goods: Literature review of theoretical and empirical evidences. International Journal of Scientific \& Engineering Research, 4(12), 250-255.

Müller, A., Smits, D.J., Claes, L., Gefeller, O., Hinz, A., \& Zwaan, M.D. (2013). The German version of the material values scale. Psycho-Social-Medicine, 10. https://doi.org/10.3205/psm000095

O’Cass, A., \& Frost, H. (2002). Status brands: Examining the effects of non-product-related brand associations on status and conspicuous consumption. Journal of Product \& Brand Management, 11(2), 67-88. https://doi.org/10.1108/10610420210423455

O’Shaughnessy, J., \& O'Shaughnessy, N.J. (2002). Marketing, the consumer society and hedonism. European Journal of Marketing, 36(5/6), 524-547. https://doi. org $/ 10.1108 / 03090560210422871$

Podoshen, J., Li, L., \& Zhang, J. (2010). Materialism and conspicuous consumption in China: A cross-cultural examination. International Journal of Consumer Studies, 35(1), 17-25. https://doi.org/10.1111/j.1470-6431.2010.00930.x

Podoshen, J., \& Andrzejewski, S. (2012). An examination of the relationships between materialism, conspicuous consumption, impulse buying and brand loyalty. Journal of Marketing Theory and Practice, 20(3), 319-334. https://doi.org/10.2753/ MTP1069-6679200306

Ray, N.M. (2009). Household consumption in ancient economies: Pompeii and The Wider Roman World. Retrieved 23 May 2017 from https://lra.le.ac.uk/handle/2381/8465 
Richins, M.L. (1994). Special possessions and the expression of material values. Journal of Consumer Research, 21, 522-533. https://doi.org/10.1086/209415

Richins, M., \& Dawson, S. (1992). A consumer values orientation for materialism and its measurement: Scale development and validation. Journal of Consumer Research, 19(3), 303-316. https://doi.org/10.1086/209304

Segal, B.W., \& Podoshen, J.S. (2013). An examination of materialism, conspicuous consumption and gender differences. International Journal of Consumer Studies, 37(2), 189-198. https://doi.org/10.1111/j.1470-6431.2012.01099.x

Segev, S., Shoham, A., \& Gavish, Y. (2015). A closer look into the materialism construct: The antecedents and consequences of materialism and its three facets. Journal of Consumer Marketing, 32(2), 85-98. https://doi.org/10.1108/JCM-07-2014-1082

Schiffman, L.G., \& Kanuk, L.L. (2004). Consumer behavior (8th ed.). New Jersey: Prentice Hall.

Scott, K., Martin, D.M., \& Schouten, J.W.(2014). Marketing and thenew materialism.Journal of Macromarketing, 34(3), 282-290. https://doi.org/10.1177/0276146714532471

Souiden, N., M'Saad, B., \& Pons, F. (2011). A cross-cultural analysis of consumers' conspicuous consumption of branded fashion accessories. Journal of International Consumer Marketing, 23, 329-343. https://doi.org/10.1080/08961530.2011. 602951

Srinivasan, R., Srivastava, R.K., \& Bhanot, S. (2014). Attitudes of young Indian consumers towards luxury brands. IOSR Journal of Business and Management, 16(7), 87-97. https://doi.org/10.9790/487X-16738797

Trigg, A. (2001). Veblen, bourdieu, and conspicuous consumption. Journal of Economic Issues, 35(1), 99-115. https://doi.org/10.1080/00213624.2001.11506342

Twitchell, J. (1999). Two cheers for materialism. The Wilson Quarterly, 23(2), 16-26.

Vigneron, F., \& Johnson, L.W. (1999). A review and a conceptual framework of prestigeseeking consumer behavior. Academy of Marketing Science Review, 9(1), 1-22.

Wang, Y., \& Griskevicius, V. (2013). Conspicuous consumption, relationships, and rivals: Women's luxury products as signals to other women. Journal of Consumer Research, 40(5), 834-854. https://doi.org/10.1086/673256

Wong, A., \& Zhou, L. (2005). Consumers' motivations for consumption of foreign products: An empirical test in the People's Republic of China. Global Working Papers, 4, 1-12. https://doi.org/10.2139/ssrn.1606345

Wong, N.Y. (1997). Suppose you own the world and no one knows? Conspicuous consumption, materialism and self. Advances in Consumer Research, 24, 197203.

Workman, J.E., \& Lee, S.H. (2011). Materialism, fashion consumers and gender: A cross-cultural study. International Journal of Consumer Studies, 35(1), 50-57. https://doi.org/10.1111/j.1470-6431.2010.00935.x 